\title{
The role of Muslim women in political life based on the examples of selected Muslim countries
}

\begin{abstract}
The topic of those publication is the role of Muslim women in political and social life. Presents the first women in Islam, which played an important role in politics. Presents some Muslim countries and the presence of women in the governments of these countries. It describes the degree of their involvement in politics. Discusses the factors that affect the growth of the role of women in the political arena and those that limit their participation in political and social life. You'll find the answer to the question whether the high rate of GDP has an impact on women's involvement in social and political life.
\end{abstract}

Key words: development of women, the Middle East, Islam

$\mathbf{T}$ he following paper is an attempt to analyze both liberal and conservative, rich and poor Muslim countries of different political and cultural systems, and to address the following issues: Why is women's participation in politics constantly growing? What drives an increased participation of women in politics? Are high GDP rate and considerable affluence of societies in some Muslim countries influencing women's chances for succeeding in politics? To what extent does the poly-ethnic structure of some Muslim countries impact women's involvement in political life?

In the course of the last several years the need for constructive dialogue and understanding leading to women's participation in politics have grown in both in Muslim and non-Muslim countries. Various organizations including political parties enable women's active participation in political and social reality and help them fight for their rights. In most cases political parties admit women into their structures not because they believe in their skills and qualifications, but rather to improve their image. This is led by the constant development, western countries emphasizing the importance of women's involvement in political life or increasingly growing influence of the mass media.

Muslim critics believe that politics and women do not go together as women lack experience, leadership skills and they are too emotional. Deeply rooted in Muslim culture and tradition women should indulge in the family life rather than try to delve into the intricacies of political world which is demanding and asks for a lot of sacrifices. Quoting the words of the Prophet saying that a man may ask for his woman's advice, however he has no obligation to follow her opinion (Bin Qanna, 2002), it is easily noticed that the Persian Gulf states did not allow for women's involvement in political life for a long time. This attitude is still existent especially in Saudi Arabia. The only exception was that women were given the possibility to advise the so-called Advising Council (Majlis-ashShura) in the matters concerning them, however they still could not vote in the Council. In September 2011 king Abdullah ibn Abdulaziz Al-Saud issued a decision stating that in the following elections women would enjoy full rights to run for the positions of the 
Council members and local government members (Al-Sahil, Al-Rashid, 2011). On the $11^{\text {th }}$ January 2013 the king nominated 30 women (the Council has 150 seats) holding $\mathrm{Ph}$.D. titles in various disciplines to Majlis-ash-Shura Council. In accordance with the rules of the Muslim religion in Saudi Arabia a separate part of the building and a separate entrance to the building were designated to them. These women became also members of all Advising Council Commissions (Al-Harif, 2013).

Although there is no specific fragment concerning the role of a woman in politics neither in Quran, hadiths nor in Ijma, Muslim fundamentalists believe that the participation of women in political life is against their religion. According to this religion, women should stay at home. An exception to this rule may be some higher necessity or social interest which may allow women to leave their homes. "Men are in charge of women by right of what Allah has given one over the other and what they spend for maintenance from their wealth. So righteous women are devoutly obedient, guarding in the husband's absence what Allah would have them guard. But those wives from whom you fear arrogance - first advise them; then if they persist, forsake them in bed; and finally, strike them. But if they obey you once more, seek no means against them. Indeed, Allah is ever Exalted and Grand" (Quran, 1986, p. 99).

Supporters of the increased women's participation in politics are often faced with the statement that a nation led by a woman will never succeed. The only case when a woman should stay at home refers to the women of the Prophet or those who committed adultery. Until recently such women were penalized in the form of a home arrest. Since God sent a surah on Women, this penalty changed. "Those who commit unlawful sexual intercourse of your women - bring against them four witnesses from among you. And if they testify, confine the guilty women to houses until death takes them or Allah ordains for them another way" (Quran, 1986, pp. 95-96).

Supporters of women's participation in politics often point to the example of a nation led by a woman - the daughter of Xerxes, who took over power after the death of her father. As a reminder, Mahomet, who was waging a war, was convinced that the daughter would not be able to govern without adequate experience. Therefore, it may be concluded that the words of the Prophet may not be generalized to concern all women.

It is worth mentioning the first women in Islam who played a significant role both in social and political life. One of such women was Khadiyah - the first wife of the Prophet - who was also the first to believe in her husband's mission (Bayumi, 2011). The migration of some Muslim women goes back to the times of Mahomet. Women took part in his escape from Mecca to Medina, they got involved in fierce political battles and joined opposition of the government. Some of them occupied significant positions, like e.g. in the times of the second Mecca caliph, Omar bin Hattab (Abu Faris, 2000, p. 142), when Al-Shifa bint Abdullah made sure that the inhabitants obeyed the public order and followed the rules of religious life.

Aisza bint Abu Bakr, the youngest wife of the Prophet is yet another example of a woman who started to actively participate in social life after her husband's death. She was considered a remarkable person, the author of the Muslim law, and most caliphs had to respect her opinion. She was able to quote nearly a thousand speeches of Mahomet. In the times of the fourth Mecca caliph's rule, Ali ibn Abi Talib fought against Ali. 
Some of the factors that reduced women's participation in political life include customs and tradition. The Muslim world is highly diverse. In most countries the customs are over-conservative. This does not mean however that there are no countries enjoying pretty liberal system. The existing situation is closely related to the extent of religiosity and the country of origin, it also depends on the level of education of the society and their attitude towards western culture.

It may be noticed that the citizens of religiously and ethnically homogenous countries, such as Saudi Arabia, United Arab Emirates, Oman, Kuwait or Yemen tend to be less tolerant than the citizens of more heterogenic countries. It is worth emphasizing that in Syria, Lebanon, or Egypt, countries which showed a considerable degree of liberalism towards the religion and ethnicity, the level of education was relatively high, and women had unrestricted access to it. It was also in Syria where women were the first to be given right to vote and run for political offices - in 1950, the Kingdom of Saudi Arabia gave their women right to vote as late as in 2013 (Redman, 2011).

Muslim women have to come a long way before they can actively participate in public life. This is because from the very beginning this kind of activity was reserved for men only. The role of a woman was limited to carrying out house works and raising children. The very religion of Islam does not encourage letting women to serve public offices. The constantly increasing progress of societies eliminates cultural barriers giving women chances for education and participation both in social and political life.

Over the course of centuries the opinions and orders of religious authorities have been changing. Depending on the country, either liberal or more conservative attitudes were dominating. More liberal societies gave women a chance or even a right to take over power, while in more conservative societies a woman could become Prime Minister, but higher offices were reserved for men.

Some Muslim countries decided to introduce the so-called quota system guaranteeing that from $10 \%$ to $20 \%$ of the names on voting lists would be women (Al-Madani, 2011). There was a risk, however, that the society so deeply rooted in conservative culture would not be willing to cast their votes for female candidates. Therefore, the authorities decided not to depend on the moods of the society and supported women's participation in politics by implementing the quota system. Thanks to this system, the law guarantees women a batter start to professional life and active participation in politics. In most countries where the quota system was introduced, it was proved it definitely improved the government's image.

The opponents of the quota system believe that the system infringes equal treatment of citizens by giving privileges to women only, which, in their opinion, is not fair. They even point to their constitution which clearly state that all citizens, both men and women, are equal according to the law, hence none of these groups should be favored. Some of the countries that implemented the quota system and proved that well-educated women are able to occupy the positions of deputy PM's are : Egypt, Sudan, Morocco, Jordan, Iraq and Tunisia.

Women's participation in politics in some Muslim countries:

\section{a) Oman}

Statistics as of 2002 demonstrate that four important ministerial positions of undersecretaries are occupied by women: The work in the Ministry of Science and Higher Edu- 
cation, the Ministry of National Education, The Ministry of Economy and the Ministry of Social Development (Redman, 2011). The number of women running for political offices juxtaposed to the number of men bears no comparison. Elections to Majlis-ashShura from 1997 best demonstrate this trend, as there were 529 men versus 21 women running for the office, and only 2 of them managed to collect sufficient number of votes to be admitted (Bin Qanna, 2002).

Women in Oman are in favor of introducing the quota system that would give guarantee for equal support in elections. The author of this paper believes this is a fair solution, although in a way it infringes the democratic system.

\section{b) Lebanon}

Lebanon is a liberal country inhabited in $50 \%$ by Christians. Even though Lebanese women have enjoyed political rights and high social position since 1952, none of them ever served as a prime minister or president. The breakthrough came in 2000 when three women became members of the Parliament. In 2004 two women were appointed government ministers (Redman, 2011). The quota system introduced in 1996 may have contributed to that fact. Initially women wanted that 14 seats representing $10 \%$ of all seats would be assigned to female candidates (Al-Madani, 2011). Some concerns that the bill would not be passed due to the domination of men led to yet another solution, which was to add to 128 seats in Parliament another 14 seats for women and in this way keep all 128 seats for men only. Another step was to increase the percentage rate from $10 \%$ to $30 \%$, however this idea was never put in place. Apparently, even in a country as democratic as Lebanon is, women has no chances for entering politics in a democratic way. The situation of women is slightly better in Egypt, Morocco, Syria and Iraq, where the percentage rate of women's participation in politics ranges from $10 \%$ to $25 \%$.

\section{c) Hashemite Kingdom of Jordan}

In 1974 the Bill on the election law no. 9 was amended and it included the right for women to run for Parliament seats (Abu Jbrail, 2011), and since 1982 they have had the right to run for offices in local governments. In practice women could participate in political life in the sense of running for political offices not sooner than in 1989. 12 women were then fighting for mandate, however none of them succeeded. The first female candidate who entered the Parliament in 1993 out of 3 other candidates was Tojan Faisal - a representative of Cherkess-Chechen minority (Al-Khathlan, 2007, p. 95).

In 2001 the elections were repeated due to the death of one of the MPs, as a result of which the mandate was won by a woman (Ferid, 2011). In 2003 female representatives were assigned additional 6 seats in the Parliament just as in 2007. It is worth indicating that a female government minister was appointed for the first time in 1979, then in 1994, 1995, and finally in 2000 a woman was appointed deputy prime minister (Haddad, 2001, p. 108).

\section{d) Yemen}

Yemen constitutes one of the most conservative and inflexible countries due to its tribal structure and severity of the Muslim culture. In the times when Yemen was divided, women from the southern part of the country enjoyed cultural and social freedoms, and 
they took advantage of voting rights. This resulted from the fact that the pro-Moscow People-Democratic Republic of Yemen (the so-called Southern Yemen) was under the influence of the Soviet Union. In 1990 the Republic of Yemen (the so-called Northern Yemen) and Southern Yemen united and formed Modern Republic of Yemen (Al-Kurdi, 2011). The situation of women there deteriorated significantly. This is best demonstrated by the decreasing number of women in the political life: in the 1993 elections 48 women were running for the office and only two of them succeeded, in 199723 women were running for the office and again two of them succeeded, whereas in 2003 only 11 candidates were running for the office, one of whom made it to the Parliament (Redman, 2011).

It may be expected that the situation of women will gradually improve due to their active participation in the uprising against the regime of president Ali Abd Allah Salih in 2011. It is also significant that the Norwegian Noble Committee awarded Peace Nobel Prize to a Yemeni journalist fighting for women's right Tawakkul Karman (Abu Al-Samh, 2011).

\section{e) Syria}

As opposed to other Arabic countries the people of Syria are definitely better educated and the position of women is considerably higher. Even though the country is inhabited by multiple nationalities (Arabs, Kurds, Armenians, Turkmen, Assyrian people, Cherkess and other) and religious groups (the Shia, the Sunni, Alawites, the Druze, Christians, Greek Catholics, Yazidis, the Jews) (Abu Al-Samh, 2011), Syria is one of the countries where women received voting rights relatively early, in 1949. The first woman made it to the Parliament in 1954 (Shaaban, 2008, p. 135). In 1960 the Parliament consisted of 200 members, $1 \%$ of which accounted for women (Al-Ajlani, 2011). Notwithstanding a very low number of women, two of them were appointed MPs. Since 1971 the participation of women in the Parliament has been significantly growing thanks to the fact that they are supported by the leaders of Al-Baas party. In 19658 women were elected to the Parliament out of a total of 95, whereas in 1966 - 13 out of a total of 134. In 1998518 women were running for MPs positions, while in the subsequent elections this number grew to 849 (Dawr al-maraa, 2011).

The year 2006 marked a breakthrough for the country of Syria when for the first time in the Arabic world Najah al-Attar, the former minister of culture in the years 19762000 , became the second vice-president for culture. In the same year 6 women served as ambassadors in the Diplomatic Corpse. For more than ten years the number of women occupying high public positions is also rising, especially when it comes to the justice sector they serve as judges or persecutors). Currently the percentage of women seating in the Parliament amounts to $12 \%$, and the President's advisor in the matters of politics and media is Bouthaina Shaaban (Shaaban, 2008, p. 135). In reality, the participation of women in politics is not determined by the democratic choice made by the society. The decision is taken by the leaders of Al-Baas party led by Bashar-al-Assad who has been in power since 1963 .

\section{f) Egypt}

Egypt stands for one of the countries where women were the first to become MPs. According to the statistics, in 1957, 2 women out of a total number of 350 candidates en- 
tered the Parliament, in 1960, 2 out of a total of 300, in 1964, 5 out of a total of 363, in 1971,4 out of a total of 362, in 1976, 3 out of a total of 361 (Al-Madani, 2011). Since the quote system was introduced in 1979 the participation of women in the Parliament has significantly grown. After the elections held in 1984 and then 1987, there were 35 women MPs for a total number of 360 members. Soon after the quota system was lifted and so the number of female MPs dropped sharply: in 1990 there were 7 female MPs, in $1995-9$, in $2000-10$, in 2005 - 10, 4 of whom were nominated (Al-Madani, 2011).

Table 1

Participation of women in the parliaments of selected Arabic countries

\begin{tabular}{|l|c|c|c|c||}
\hline \multicolumn{1}{|c|}{ Country } & $\begin{array}{c}\text { Month and year } \\
\text { of the elections }\end{array}$ & $\begin{array}{c}\text { Number of seats } \\
\text { (total) }\end{array}$ & $\begin{array}{c}\text { Number } \\
\text { of women }\end{array}$ & $\begin{array}{c}\text { Percentage participation } \\
\text { of women }\end{array}$ \\
\hline Iraq & 12.2005 & 275 & 70 & $25.5 \%$ \\
\hline Tunisia & 10.2004 & 189 & 43 & $22.8 \%$ \\
\hline Sudan & 08.2005 & 450 & 66 & $14.7 \%$ \\
\hline Djibouti & 02.2008 & 65 & 9 & $13.8 \%$ \\
\hline Palestine & 01.2006 & 132 & 17 & $12.8 \%$ \\
\hline Syria & 04.2007 & 250 & 30 & $12.0 \%$ \\
\hline Morocco & 09.2007 & 325 & 34 & $10.5 \%$ \\
\hline Algieria & 05.2007 & 389 & 30 & $7.7 \%$ \\
\hline Jordan & 11.2007 & 110 & 7 & $6.4 \%$ \\
\hline Libya & 03.2006 & 760 & 36 & $4.7 \%$ \\
\hline Lebanon & 05.2005 & 128 & 6 & $3.1 \%$ \\
\hline Kuwait & 05.2008 & 65 & 2 & $2.0 \%$ \\
\hline Egypt & 11.2005 & 442 & 9 & $0.3 \%$ \\
\hline Yemen & 04.2003 & 301 & 1 & $0.0 \%$ \\
\hline Saudi Arabia & 04.2005 & 150 & 0 & $0.0 \%$ \\
\hline Oman & 10.2007 & 84 & 0 & $0.0 \%$ \\
\hline Bahrain & 10.2002 & 40 & 0 & $0.0 \%$ \\
\hline United Arab Emirates & 02.2003 & 40 & 0 & $0.0 \%$ \\
\hline Qatar & 06.2005 & 35 & 0 & \\
\hline
\end{tabular}

Source: Abu Jbrail N. (Hal min laiha nisaiya fi al-intihabat al-muqbila? al-kota al-nisaiya wajib ala al-dawla we haq lilmaraa), Does the list of women running for parliamentary election exist? Quota of women - the duty of the state and rights of women, http://www.ounousa.com/mashahir\%20w\%20akhbar/womenelection. htm, as of 12.09.2011.

\section{g) The Islamic Republic of Iran}

The involvement of women in political life remains at an average level. The increase of women's participation in politics was driven by the Islamic Revolution which took place in 1979 (Azizi, 2014). Several Iranian women living at the turn of the $19^{\text {th }}$ and $20^{\text {th }}$ centuries are especially worth mentioning:

1) Fatimih Baraghani (Qurrat ul-Ain), a poet, political and religious activist of the bahai movement, she was the first woman to take off hijab, she was killed for her activities. The words she uttered minutes before her death went down in history: "You may kill me, but you will not kill the emancipation of women of the East." These words ushered in a new era of equality between men and women;

2) Iran Timur-Tash, wife of a minister at the Shah court, she gave up the traditional Muslim clothes for European clothes; 
3) Ashraf Pahlavi, referred to as a strong woman from the court of her brother, Shah Mahammad Reza Pahlavi. Thanks to her charismatic nature she had an enormous influence on political decisions;

4) Mariem Fejruz, referred to as the Red Princess due to her participation in the Communist Party, for which she was arrested and sentenced to a 10-year imprisonment (Rafsanjani, 2011).

It is easily noticed that it was mostly women from aristocratic class that were engaged in a political life. This changed when the Islamic regime took over the power. Then women from the middle class engaged in politics. Before 1979 women who participated in political life were "emancipated", they were not wearing hijab or any other religious symbols and they accounted for a marginal percentage of the whole society - access to power depended on their origin. However, after 1979 a radical Islamization of Iran came and the group of the emancipated women had to escape or submit to the new order and wearing head scarf.

The Islamic Revolution of Ayatollah Khomeini (Azizi, 2014) led to the emancipation of women from lower classes. This allowed women to fight alongside men for the overturning of the Shah's regime. There were obviously some women who were not supporting the revolution. Acting in opposition to the revolutionary movements they created some structures that resembled reformation groups fighting for their rights. They were divided into three main groups:

1) women from the middle class that constituted the fundament of the group;

2) women educated in cultural and social areas;

3) women from the upper class who formed the political elite of Iran (wives, daughters) (Azizi, 2014).

Presidential elections in 1997 were won by Mohammad Chatami (Al-hayali, 2000, p. 103) supported by the Women's Movement. He was considered by women a great reformer who nominated Masoumeh Ebtekar for the position of advisor in the Centre for Peace and Environment Protection right after he took over the power. The number of female deputy minsters and directors in public institutions also rose. According to the governmental statistics as of the year 2000 as many as 525 women in Iran had their own publishing houses, 90 of them were editors-in-chief in newspapers, 97 held managerial positions in cultural institutions, 193 participated in national film festivals, 600 were registered in public libraries, over 300 were teaching at theological universities (Ihsaiyat, 2012). It is also interesting to note that more than $50 \%$ of all students are women. Taking into consideration the Parliament in 2011 women held 11 seats there and in 2006 - 12 seats (Azizi, 2014). All candidate were members of the so-called Reformative Movement and they supported Chatami. Iran is a country where the participation of women in public life is much higher in big cities than in villages.

\section{h) The Islamic Republic of Pakistan}

Pakistan is an example of a country where a woman achieved one of the highest positions in the country. Benazir Bhutto (Ambreen, 2011), a daughter of president Zulfikar Ali Bhutto murdered by the military regime in 1979 , served as a prime minister twice, first in 1988-1990 and then in 1993-1996. Before she held such a significant position, she had led the Pakistani People's Party, supported the nuclear program and wanted to 
annex Jammu and Kashmir from India. Benazir Bhutto was murdered in 2007 and the power was taken over by her husband Asif Ali Zardari (Ambreen, 2011). Hina Rabbani Khar (born in 1977) may serve as yet another example as in 2011 she became the first female minister of foreign affairs.

Women in Pakistan enjoy a wide specter of privileges. In accordance with the Constitution as of 2002, 38\% of the seats in both the lower and the upper chamber of the Parliament are reserved for women (Khan, 2013). In 2005 the number of women in the Senate amounted to 72 out of a total of 342 seats (Ambreen, 2011) which represents 21.1\%, whereas in the lower chamber of the Parliament women occupied 17 out of a total of 100 seats (Ambreen, 2011), which represented 17\%. Women in Pakistan are served out of turn, they do not wait in long queues, policemen do not fine them for traffic offenses. One of the curiosities is that a Pakistani woman, as opposes do other Muslim countries, prepares a flat to welcome her newly-wed husband. This custom is cultivated in Punjab and Sindhu provinces and it came over from India. If a man wants to remarry, he needs to get consent from his first wife.

There is a widely known group of famous Pakistani women:

1) Kalsoom Nawaz Sharif - a political activist, she replaced her husband in the Pakistani Muslim League (Zaydan, 2015);

2) Naseem Wali Khan - leader of the National Party;

3) Zubaida Jalal - Minister of National Education (Jalal, 2015);

4) Nilofar Bakhtiar - minister of Special Education and Social Care Development (Bakhtiar, 2013);

5) Malala Yousafzai, an activist fighting for women's rights, especially for their right to education, when aged 17 she was awarded a Nobel Peace Prize in 2014 as the youngest laureate in the history, persecuted by the Taliban who wanted to kill her (The Nobel, 2015).

Women in Pakistan are active across all economic sectors. They are becoming in a way a competition for men. Even though they earn less, they definitely lead in the area of education. They occupy high positions - from the Ministry of National Education to chancellors of universities. Over $90 \%$ of private school teachers are women (Ambreen, 2011). Today women are especially active in the fields of IT science and mass media. A high position of women depends to a large extent on their background. In most cases, these are the women from wealthy families who do succeed.

Women coming from villages do not have such bright perspectives. Their position is definitely lower as they are not allowed to decide about their future the way women from big cities are. What prevents them from doing so is the lack of education and illiteracy which accounts to a staggering $75 \%$ (Adnan, 2011). It is a man who decides about such a woman's future. In case her husband dies, she is not allowed to marry another man, as the brother of the departed husband has the priority.

\section{i) Turkey}

Turkey is a liberal country. However until 1924 the fate of women was largely limited by sharia (the Muslim law). They were forced to wear traditional Muslim clothes, including head covers and they were not allowed to enter public entertainment sites. A man had a right to have four wives - polygamy was omnipresent. A real breakthrough came in 
1924 when women obtained voting rights and then rights to run for political offices in 1934 (Yugonso, 2014). There were 18 women in the first Turkish parliament. The first woman in Turkey to hold a significant position was Behice Boran (Kiebała, 2014) who became the president of the Turkish Labour Party. Another important figure is Tansu Ciller (Zaid, 2013) who has served as the PM's advisor since 1991, became PM in 1993 and in 1996-1997 served as a foreign affairs minister.

The Turkish constitution guarantees the equality of all citizens irrespective of their language, race, denomination, gender or political preferences. Everyone has a right to free movement and freedom of speech. Turkey has adjusted a lot of Western world rights to its own categories. Thanks to that it is possible to strive for equality between men and women. Since 1994 a wife does not need a consent of her husband to work outside of the place she lives (Al-Dihem, 2011).

Recent elections to the Parliament demonstrate that the number of female MPs has grown from 48 in 2007 to 68 in 2011, which represents 12\% (Salha, 2015). 34 women from the Muslim-oriented Party of Justice and Development entered the Parliament. However, these women were not wearing hijab during the elections, the thing written in the religious tradition, in order to avoid criticism from other parties. A Turkish woman who is wearing a headscarf may not work in public institutions, according to the Constitution (Adad, 2014). Kurdish women who are members of the Peace and Democracy Party are also worth mentioning as they won 10 mandates out of 36 available. This is, in a way, a peculiar situation taking into account the level of conservatism in Kurdish regions of Turkey. This result proves that the significance of women in the Kurdistan Worker's Party (PKK) is growing (Based on individual observation).

A significant Kurdish woman is Layla Zana who was sentenced to a 10-year imprisonment for speaking Kurdish language in Turkish Parliament. She was accused of speaking against Turkey. In 1995 she was awarded Sakharov Prize by the European Parliament (Head, 2011). The same year she was also awarded Bruno Kreisky Prize (Al-sijin asher, 2011).

\section{Conclusion}

Women's problem are gradually gaining in interest. On the one hand Muslim countries want to admit women to political and social life, on the other they are not willing to imitate European states as their solutions are not in line with the spirit of the Muslim religion. However, they are aware that they are not able to stop the process of the society's evolution, which is accelerating given the phenomenon of globalization and scientific and technological revolution. European culture is definitely very appealing to a lot of young people, both men and women, in the Middle East. Therefore, the society is looking for alternatives that could be a golden means. The discussions regarding women's rights and their role in social and political life are held mostly at various international conferences. Modern mass media are also highly effective in this respect as they publicize the situation of women from various parts of the world and in this way encourage the authorities of some countries to engage in a constructive dialogue.

It is worth noticing that high GDP rate in some Muslim countries has no influence on the advancement of women in political life. Women from such countries have very few 
rights in public life. Statistics clearly show that women living in countries with lower GDP rate participate more actively in social and political life. This is because a man living in a rich country believes that his woman has everything she needs from life and there is no need for her to work professionally. In poorer countries, on the other hand, women very often are forced to work as men are not able to maintain their families, and this makes them also engage in social and political life.

The problem of women's participation in political life will not be solved in the near future, because it will take decades before people are able to adjust to new rules. The change of law itself is not going to change the mentality of people. What is needed is education accompanied by social progress. Liberating women from the shackles of tradition could be a viable solution. Currently, the measures implemented by some Muslim countries are effective, although they are not always democratic.

Finally, it is worth to think about the role of a woman in the contemporary world. Is she supposed to serve merely as a decoration in politics, or maybe her skills and potential could be fully made use of?

\section{Bibliography}

AbuAl-SamhA., TawakkulKarman,http://www.okaz.com.sa/new/Issues/20111010/Con20111010450199. $\mathrm{htm}$, as of 10.10.2011.

Abu Faris A. M. (Hquq al-maraa al-madaniya we al-syasya fi al-islam), Civil and political right of women in Islam, Amman 2000.

Abu Jbrail N. (Hal min laiha nisaiya fi al-intihabat al-muqbila? al-kota al-nisaiya wajib ala al-dawla we haq lilmaraa), Does the list of women running for parliamentary election exist? Quota of women - the duty of the state and rights of women, http://www.ounousa.com/mashahir $\% 20$ w\%20akhbar/womenelection.htm, as of 12.09.2011.

Adad qeyasi li al-nisaa dehelne al-barlaman al-turki we kurdiya tefuz min al-sijin (2007), A record numer of women to enter Turkish Parliament including a Kurdish woman from prison, „Al.Anbaa", no. 12812, 26.07.2007, http:/www.alanba.com.kw/AbsoluteNMNEW/templates/international2010.aspx?articleid $=14406 \&$ zoneid $=13 \& \mathrm{~m}=0$, as of 14.09 .2014 .

Adnan N. (Al-taalim fi Bakistan) (2009), Education in Pakistan, „Almarefh”, no. 102, May, http:// www.almarefh.org/news. php? action= show\&id=2304, as of 01.10.2011.

Al-Ajlani SH. (Hal al-rajul al-suri bihaja lidwrat litahsin islubahu fi al-taamul maa al-maraa), Does a Syrian man need training to improve his attitude towards women, http://www.c-we.org/ar/ show.art.asp?aid=38852, as of 04.10.2011.

AL-Dihem S. B. M. (Al-din we al-dawla. fi al-tajreeba al-turkiya), Religion and state in Turkish experience, http://islamtoday.net/nawafeth/artshow-41-147547.htm, as of 08.09.2011.

Al-Harif B. (Al-Malak Abdullah yehtar 150 idwan beynihim 30 imraa fi majlis al-shura) (2013), King Abdullah designated to The Consultative Assembly 150 members including 30 women, "Asharq Al-Awsat", nr 12464, 12.01.2013, http://www.aawsat.com/details.asp?section=4\&article=7127 51\&issueno=12464\#.UXBUukrk1qA.

Al-Hayali R. K. (Al-Islam we hiquq al-maraa al-syasya) (2000), Islam and political rights of women, Tanta.

Al-Khathlan M. S. (Al-maraa we al-syasa) (2007), Woman vs. politics, Rijad.

Al-Kurdi A. (Ahmiyet dawr al-maraa fi al-tanmiya al-syasya), The role of women in political development, http://kenanaonline.com/users/ahmedkordy/topics/68023/posts/124871, as of 18.09.2011. 
Al-Madani A. (Nizam al-kota al-nisaiya asyawiyan), Asian quota system for women, http://www. ahewar.org/debat/show.art.asp?aid=34467, as of 15.09.2011.

Al-Sahil T., Al-Rashid N. (Al-Malak Abd Allah yudhal al-Maraa majlis al-shura) (2011), King Abd Allah allows women to enter the Advisory Council, "Asharq Al-Awsat", no. 11990, 26.09.2011, $\mathrm{http}: / /$ www.aawsat.com/details.asp?section= 1 \&issueno=11990\&article=642197.

Al-sijin asher senewat li nashita kurdiya Bi tuhmet alaqatiha Bi hizib al-umal, 10 year in prison for a Kurdish activist accused of connections with PKK, http://www.aljazeera.net/news/archive/ archive?ArchiveId=1163254, as of 02.10.2011.

Ambreen N. (Al-maraa al-bakistaniya fi al-madina we al-rif), Pakistani woman in the city and in the province, http://www.almarefh.org/news.php?action=show\&id=2306, as of 19.09.2011.

Azizi Y. (Dawr al-maraa al-iraniya fi al-tatawerat al-ijtimaiya we al-syasya), The role of Iranian women in social and political life, http://www.ahewar.org/debat/show.art.asp?aid=22482, as of 13.10.2014.

Pakistani Leaders online Bakhtiar Nilofar, http://www.pakistanileaders.com.pk/profile/Nilofar_Bakhtiar, as of 28.10.2013.

\section{Based on individual observation:}

Bayumi L. (Al-dawr al-syasi lilmaraa Beyn al-manih we al-manaa), Political role of women. Permissions or prohibitions?, http://www.islamtoday.net/nawafeth/artshow-45-2784.htm, as of 15.10.2011.

Dawr al-mraa fi tenmiyet al-mujtamaa, The role of women in the development of the society, http:// www.isesco.org.ma/arabe/publications/taaliminath/P5.php, as of 04.10.2011.

Ferid A. (al-maraa fi mujtamaaina ila ain?), Where is woman in our socjety heading for?, http://www. balagh.com/woman/trbiah/zh02b111.htm, as of 14.10.2011.

Haddad K. (Al-maraa we al-amal al-syasi) (2001), Woman and political work, Damascus.

Head J., Turkey election: Leyla Zana eyes Kurdish comeback, ,,bbc news”, http://www.bbc.co.uk/news/ world-europe-13698915, as of 09.09.2011.

Jalal Z., The Federal Education Minister, http://www.sachet.org.pk/web/page.asp?id=615, as of 28.10.2015.

Khan S. (Al-maraa al-bakistaniya leha mekana hassa biha), Pakistani woman has a special place for herself, http://www.commongroundnews.org/article.php?id=28899\&lan=ar\&sid=1\&sp=0, as of 20.09.2013.

Kiebała M., Woman in Turkish law, http://www.politykaglobalna.pl/2009/03/kobieta-w-prawietureckim/, as of 08.09.2014.

Qanna K. (Mushareket al-maraa fi al-hayat al-syasya), The participation of women in political life, Al Jazeera Channel, http://www.aljazeera.net/channel/archive/archive?ArchiveId=90442, 25/02/2002.

Quran (1986), Surah 4-Women, verse 15, translation: J. Bielawski, Warsaw.

Quran (1986), Surah 4-Women, verse 34, translation: J. Bielawski, Warsaw.

Rafsanjani H. F. (Dawr al-maraa al-iraniya), Role of Iranian women, http://www.albainah.net/index. aspx? function= Item\&id=1340\&lang=, as of 09.09.2011.

Redman T. M. Q. (Al-kota ahed wesail rafaa mistawa tamseel al-maraa fi al-sulta al-tashreeiya fi al-yamen we al-duwal al-arabiya), Quota - one of the ways to increase the participation of women in law-making in Yemen and Arabic countries, http://www.ahewar.org/debat/show.art. asp?aid=194545, as of 12.10.2011.

Salha S. (Al-nisaa fi turkiya), Women in Turkey, http://israelkurd.com/ar/index.php?option=com content\&view $=$ article\&id $=745: 2011-04-20-20-25-39 \&$ catid $=37: 2010-05-14-12-48-37$, as of 01.08.2015. 
Shaaban B. (Al-maraa fi al-syasa we al-mujtamaa) (2008), Woman in politics and society, Damascus.

The Nobel Peace Prize 2014, Nobelprize.org, The Official Website of the Nobel Prize, http://www. nobelprize.org/nobel_prizes/peace/laureates/2014/, accessed 19.06.2015.

Yugonso C. (Al-maraa al-Turkiya), Turkish woman, ,,Al-bilad”, http://209.235.200.201/ albiladp/ column_inner.php?wid=2989\& colid $=656$, as of 26.09 .2014 .

Zaid H. (Indama tahkoom al-nisaa al-alam), When do women govern the world?, http://www.maghress. com/almassae/8306 as of 18.09.2013.

Zaydan A. (Bakistan we hukom al-ailat), Pakistan and family rule, http://www.aljazeera.net/NR/exeres/ED11EC29-DED2-478F-A04B-2A7BBFD073D2.htm, as of 01.10.2015.

\section{Rola kobiet muzułmańskich w życiu politycznym na przykładzie wybranych państw}

\section{Streszczenie}

Tematem publikacji jest rola kobiet muzułmańskich w życiu politycznym i społecznym. Przedstawione zostały pierwsze kobiety w islamie, które odegrały ważną rolę w polityce. Na przykładzie wybranych krajów muzułmańskich opisano obecność kobiet w rządach tych krajów i stopień ich zaangażowania w politykę. Omówione zostały czynniki, które wpływają na wzrost roli kobiet na arenie politycznej oraz te, które ograniczają ich udział w życiu politycznym i społecznym. W artykule znajduje się odpowiedź na pytanie, czy wysoki wskaźnik PKB ma wpływ na zaangażowanie kobiet w życie społeczne i polityczne.

Słowa kluczowe: rozwój kobiet, Bliski Wschód, Islam, kobiety muzułmańskie 